\title{
Composition of cholesterol and its precursors in ovine milk
}

\author{
Hanane GOUDJIL ${ }^{\mathrm{a}}$, Susana TORRADO ${ }^{\mathrm{a}}$, Javier FONTECHA ${ }^{\mathrm{a}}$, \\ Isabel MARTÍNEZ-CASTRO ${ }^{\mathrm{b}}, \mathrm{M}^{\mathrm{a}}$ Jesús FRAGA $^{\mathrm{c}}$, Manuela JUÁREZ ${ }^{\mathrm{a} *}$ \\ ${ }^{a}$ Instituto del Frío (CSIC) Ciudad Universitaria s/n, 28040 Madrid, Spain \\ b Instituto de Química Orgánica General (CSIC) Juan de la Cierva, 3, 28006 Madrid, Spain \\ c Universidad Politécnica, 28040 Madrid, Spain
}

(Received 8 April 2002; accepted 11 October 2002)

\begin{abstract}
Identification and concentration of cholesterol and its precursors were investigated in ovine milk. In order to ensure a wide variety of milk composition, 45 samples were taken during the year from the bulk milk of five herds (ranging from 130 to 2500 adult ewes) corresponding to five breeds and located in different places in Spain. Gas chromatography/mass spectrometry analysis allowed the identification of small quantities of squalene, lathosterol, desmosterol, dihydrolanosterol and lanosterol. Neither campesterol nor $\beta$-sitosterol could be detected in the studied samples. The mean values (mg. $100 \mathrm{~g}^{-1}$ fat) were: cholesterol $288.44 \pm 42.22$; squalene $1.80 \pm 0.99$; lathosterol $1.81 \pm 0.82$; desmosterol $0.41 \pm 0.30$; dihydrolanosterol $4.15 \pm 2.40$ and lanosterol $6.86 \pm 1.88$. With the statistical model used, the cholesterol concentration in milk fat was shown to be influenced by an interaction between the factors time of year of sampling and breed, but the variations observed do not show a clear trend.
\end{abstract}

\section{Cholesterol / minor sterols / ewe milk / fat / gas-chromatography / mass-spectrometry}

Résumé - Composition du cholestérol et de ses précurseurs dans le lait de brebis. L'identification du cholestérol et ses précurseurs a été effectuée sur le lait de brebis et leur concentration mesurée. Afin de garantir une large variété de composition du lait, 45 échantillons ont été prélevés tout au long de l'année sur une quantité de lait de cinq troupeaux (allant de 130 à 2500 agnelles adultes) correspondant à cinq races et localisées dans différentes régions d'Espagne. L'analyse par chromatographie gaz/spectrométrie de masse a permis d'identifier une petite quantité de squalène, lathosterol, desmosterol, dihydrolanosterol et lanosterol. Ni le campesterol ni le $\beta$-sitosterol ne pouvaient être détectés dans les échantillons étudiés. Les valeurs moyennes (mg. $100 \mathrm{~g}^{-1}$ de matière grasse) ont été : cholestérol 288,44 $\pm 42,22$; squalène 1,80 $\pm 0,99$; lathosterol $1,81 \pm 0,82$; desmosterol 0,41 $\pm 0,30$; dihydrolanosterol 4,15 $\pm 2,40$ et lanosterol $6,86 \pm 1,88$. Les modèles statistiques utilisés ont permis l'observation d'une interaction entre l'effet période de l'année pour l'échantillonnage et la race sur la concentration du cholestérol dans la matière grasse du lait, mais les variations observées ne furent pas claires.

Cholestérol / stérol mineur / lait de brebis / matière grasse / chromatographie gaz / spectrométrie de masse

* Correspondence and reprints

Tel.: (34) 915492300; fax: (34) 915493627; e-mail: mjuarez@if.csic.es 


\section{INTRODUCTION}

The study of the milk fat sterol fraction is of great interest from a nutritional point of view and can also contribute to quality control of dairy products $[3,26]$. The main component of the sterol fraction is cholesterol (cholest-5-en-3 $\beta$-ol) $\left(\sim 300 \mathrm{mg} \cdot 100 \mathrm{~g}^{-1}\right.$ of fat, equivalent to $10 \mathrm{mg} \cdot 100 \mathrm{~mL}^{-1}$ of cow's milk), which comes mainly from exchange with plasma, and for a little part (20\%) from in situ synthesis [10]. Small amounts of other sterols, involved in the cholesterol biosynthesis, have also been found: in bovine milk, lanosterol (lanost8,24-dien-3 $\beta$-ol) and dihydrolanosterol (lanost-8-en-3 $\beta$-ol) have been isolated and properly characterised [9]. The presence of desmosterol (cholest-5,24-dien-3 $\beta$-ol),

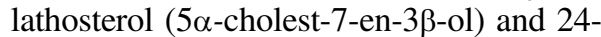
methylenecholesterol has also been reported in bovine milk [27]. Addeo et al. [1] detected desmosterol, lathosterol, and lanosterol in buffalo's milk. The same sterols with dihydrolanosterol were identified in goat's milk [14]. Human milk contains desmosterol [12], lathosterol, dihydrolanosterol, lanosterol, a dimethylsterol

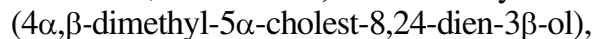
methostenol ( $4 \alpha$-methyl-5 $\alpha$-cholest- 8,24 dien-3 $\beta$-ol) and squalene [21]. There is not enough information about the content of cholesterol and other sterols in ewe's milk; however, some authors have reported a slightly higher level of cholesterol as compared with cow's milk [13].

Milk fat contains no significant amounts of plant sterols [18]. According to IDF [20], cow's milk fat contains less than $1 \%$ of plant sterols (phytosterols). Since $\beta$-sitosterol (quantitatively the most significant of the phytosterols) is considered to be a vegetable fat or oil constituent, it is important to establish with precision the maximum level of $\beta$-sitosterol naturally present in ewe's milk in order to detect adulterations. García-Olmedo et al. [15] identified traces of two vegetable sterols in the sterol fraction of ewe's milk fat: campesterol and $\beta$-sitosterol; cholesterol represented $98.68 \%$ of the total sterols. The same authors also identified lanosterol and dihydrolanosterol in the alcoholic terpenic fraction and isolated other components that could not be identified [16].

This paper deals with the identification of sterols (cholesterol and its precursors) in ovine milk fat and their quantitative determinations using an alkali-catalysed transesterification procedure with $\mathrm{KOH}-$ methanol and gas chromatography (GC) and GC-mass spectrometry (GC-MS) analysis.

\section{MATERIALS AND METHODS}

\subsection{Samples and standards}

Milk samples were collected at monthly intervals during the milking period from five ovine herds. They were taken from the storage tanks containing milk from the whole herd. Each herd consisted of a different breed: $\mathrm{CH}$ (Churra breed with 130 head), W (Awassi breed with 2500 head), $\mathrm{A} \times \mathrm{C}$ (cross between Assaf and Castellana breeds with 170 head), M (Manchega breed with 2200 head) and A (Assaf breed with 480 head). The herds were located in different places in Spain to ensure a wide variety of milk composition. For statistical analysis, the samples were distributed into four groups or seasons: Jan, Feb and Mar; Apr, May and Jun; Jul, Aug and Sep; Oct, Nov and Dec (1, 2, 3 and 4 respectively).

A total of 45 samples were collected over the year. The samples from the herds of breeds $\mathrm{M}$ and $\mathrm{W}$ were distributed between January and December (12 samples/ herd). The number of samples per herd for the other breeds was adjusted to the duration of lactation (7 months on average), because births were clustered.

$5 \alpha$-cholestane, which was used as an internal standard for quantitative purposes, and the sterol standards that were used for qualitative analysis were purchased from 
Sigma (Sigma-Aldrich Química, Madrid, Spain) and found to be pure (>99\%), except lanosterol which contained about 30-40\% dihydrolanosterol.

\subsection{Sterol analysis}

Fat was extracted following a procedure described by Alonso et al. [4] and frozen at $-20{ }^{\circ} \mathrm{C}$ in amber vials until analysis. For preparation of methyl esters, the fat was esterified as described by Christopherson and Glass [11]. Methyl esters, containing the sterol fraction, were directly analysed by GC. For quantitative determinations, $100 \mu \mathrm{L}$ of a solution of $5 \alpha$-cholestane $\left(2.18 \mathrm{mg} \cdot \mathrm{mL}^{-1}\right.$ hexane) was added to about $100 \mathrm{mg}$ of fat weighed to $0.1 \mathrm{mg}$ as internal standard. The response factor for cholesterol versus $5 \alpha$-cholestane was determined using cholesterol $/ 5 \alpha$-cholestane mixtures. The different samples of ewe's milk fat were analysed two times with two injections each. The repeatibility of the analytical method for cholesterol and minor sterols was verified by three determinations and three injections of several samples [3].

For identification of minor sterols, the unsaponifiable fraction of some samples was prepared following a standard procedure [20].

\subsection{Gas chromatography conditions}

GC analysis of sterols was performed on a Model AutoSystem gas chromatograph (Perkin-Elmer, Beaconsfield, UK) equipped with a flame-ionisation detector and a capillary column $(30 \mathrm{~m} \times 0.22 \mathrm{~mm} \times$ $0.10 \mu \mathrm{m})$ coated with Rtx-65TG (65\% diphenyl, 35\% dimethyl polysiloxane) (Resteck, Bellefonte, PA, USA). The carrier gas was He with a flow of $1.3 \mathrm{~kg} \cdot \mathrm{cm}^{-2}$ and a split ratio $1: 40$, the column temperature was $280^{\circ} \mathrm{C}$ and the injector and detector temperature was $350^{\circ} \mathrm{C}$. Peak were first tentatively identified by comparison of relative retention times with pure standards followed by confirmation by mass spectrometry.

\subsection{Gas chromatography-mass spectrometry conditions}

The same column described above was installed in a HP-6890 gas chromatograph with a 5973 quadrupole mass detector working in EI mode at $70 \mathrm{eV}$ (both from Agilent Technologies, Palo Alto, CA, USA), with He as carrier gas. Temperatures were $320{ }^{\circ} \mathrm{C}$ for the injector and $270{ }^{\circ} \mathrm{C}$ for the column.

\subsection{Statistical analysis}

Statistical analysis consisted of two-way analysis of variance, namely the breed and the season. General Lineal Models (two ways) and one-way ANOVA [for each season: one-way (breed) and for each breed: one-way (season)] and a paired test (Bonferroni) using SPSS 10.0 for Windows 98 were used. To calculate dependencies between parameters, pooled correlation analysis was performed defining the two groups in terms of the two effects: season and breed.

\section{RESULTS AND DISCUSSION}

\subsection{Identification}

The chromatograms of methylated samples of ewe's milk fat containing the sterol fraction showed a profile similar to that found in goat's milk fat [14], with a large cholesterol peak and minor quantities of other components appearing with the relative retention times (RRT) to cholesterol shown in Table I. GC-MS analysis allowed the identification of small quantities of squalene, desmosterol, lathosterol, dihydrolanosterol and lanosterol. These sterols have also been found in milk from species other than sheep $[1,9,14,21]$ and their presence in milk can be explained by the fact that they are intermediate products in cholesterol biosynthesis from squalene.

Some small peaks appearing in the chromatograms had RRTs similar to those 
Table I. Mean concentration of squalene and different sterols found in ewes' milk fat (mg.100 g-1 fat).

\begin{tabular}{lclcl}
\hline $\begin{array}{l}\text { Retention } \\
\text { time* }\end{array}$ & Peak No. & Identification & Mean \pm SD & Mass fragments m/z \\
\hline 0.56 & 1 & Squalene & $1.80 \pm 0.99$ & $410,137,121,149,367,341,191$ \\
1.00 & 2 & Cholesterol & $288.44 \pm 42.22$ & $386,301,275,368,353,255$ \\
1.11 & 3 & Lathosterol & $1.81 \pm 0.82$ & $386,255,371,213,273$ \\
1.15 & 4 & Desmosterol & $0.41 \pm 0.30$ & $384,271,369,213,300,351$ \\
1.32 & 5 & Dihydrolanosterol & $4.15 \pm 2.40$ & $428,413,395,273,315,241$ \\
1.44 & 6 & Lanosterol & $6.86 \pm 1.88$ & $426,411,393,315,241,273$ \\
\hline
\end{tabular}

* Relative retention time to cholesterol.

corresponding to campesterol and $\beta$-sitosterol, but their mass spectra were very poor and could not be clearly assigned to these. An experiment was run working in SIM (selected ion monitoring) mode: ions at 382 and 400 were selected for campesterol, and ions at 303 and 414 for $\beta$-sitosterol. Very small peaks appeared at the expected retention times, but these ions could also be present in the spectra of some methylsterols or dimethylsterols, so that the identification of both phytosterols is doubtful. They would be present if at all at a trace level (less than $0.1 \mathrm{mg} \cdot 100 \mathrm{~g}^{-1}$ fat), in which case the detection of vegetable oils added to ewe's milk fat may be suitable.

In some chromatograms two peaks with RRT of 1.29 and 1.41 were detected at a trace level. The RRT and mass spectra were consistent with those of cholest-4-en3-one and cholest-4,6-dien-3-one, respectively. As these products (probably resulting from cholesterol oxidation) have not been reported in milk fat, they were probably formed during the transesterification step [5]. Similar concentrations have been found in freshly prepared unsaponifiables and higher concentrations in some unsaponifiables, stored for several weeks at $4{ }^{\circ} \mathrm{C}$ in the presence of air.

\subsection{Quantification}

Table I shows the mean values and standard deviations for squalene, cholesterol and other minor sterols, obtained in duplicate injections of two methylated aliquots from each fat sample. Mean cholesterol content was $288.44 \mathrm{mg} \cdot 100 \mathrm{~g}^{-1}$ of fat and varied from 209 to $441 \mathrm{mg} \cdot 100 \mathrm{~g}^{-1}$ of fat. Al-Khalifah and Al-Kahtani [2] reported rather low mean values for the cholesterol content in ovine ghees (265 mg. $100 \mathrm{~g}^{-1}$ fat). The values reported by Haddadin et al. [17], which varied from 14.9 to $18.2 \mathrm{mg}$ of cholesterol per $100 \mathrm{~mL}$ of milk (with a mean value of $16.5 \pm 0.34$ ), were also low. A high variation interval in the cholesterol content in ewes' milk was reported: from 15 to $30 \mathrm{mg} \cdot 100 \mathrm{~mL}^{-1}$ [7]. The range of variation observed in other species has also been very high: from 204 to $382 \mathrm{mg}$ of cholesterol per $100 \mathrm{~g}$ of cow's milk fat [25].

Using a comparable number of samples of goat's milk, Fraga et al. [14] obtained a range of variation similar to that in the current work; the mean value expressed as fat content was higher $\left(342 \mathrm{mg} \cdot 100 \mathrm{~g} \mathrm{~g}^{-1}\right.$ of fat) than in ewe's milk. Fletouris et al. [13] obtained the following values in ovine, bovine and caprine milks: $21.7 \pm 0.32$, $12.2 \pm 0.18$ and $14.4 \pm 0.22 \mathrm{mg} \cdot 100 \mathrm{~g}^{-1}$ of milk; the content in ewe's milk is similar to that found in this study.

Table I also shows the concentrations of the minor sterols. The total content of minor sterols varied from 4.20 to $35.16 \mathrm{mg} \cdot 100 \mathrm{~g}^{-1}$ of fat, representing 2 to $7 \%$ of the total sterol fraction. There are no data in the literature about the content of minor sterols in ewe's milk. The proportions 


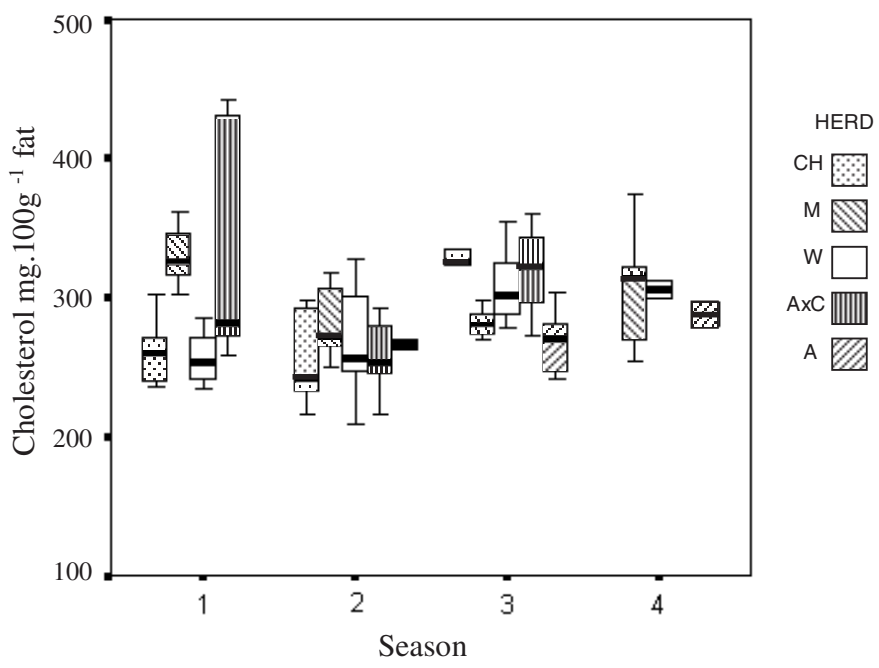

Figure 1. Evolution of cholesterol content (mean values and ranges) in ewe's milk fat for the different breeds through the seasons (Box-Wiskers presentation).

found in goat's and human milk were similar $[14,21]$. Although desmosterol is quantitatively the main minor sterol in human milk [21], lanosterol, which was first isolated in fat wool and yeast [24] and which is commonly accompanied by dihydrolanosterol in nature, was the most significant minor sterol found in the current study on ewe's milk (2.65 to $13.63 \mathrm{mg} \cdot 100 \mathrm{~g}^{-1}$ of fat). This is consistent with data reported for cow's milk [27] and goat's milk [14]. Squalene content averages $1.80 \mathrm{mg} \cdot 100 \mathrm{~g}^{-1}$ of fat (from 0.52 to 4.56 ), representing $0.6 \%$ of cholesterol.

\subsection{Effect of breed and season on cholesterol content}

Figure 1 shows the mean values and ranges of cholesterol content for the various breeds and seasons.

Application of the first of the models considered (two-way ANOVA: season and breed) revealed an interaction between the two effects, and therefore the following models were applied: model 1 , for each season a one-way ANOVA (breed); and model 2, for each breed a one-way ANOVA (season). Both models were supplemented with multiple comparisons using the Bonferroni test.

In model 1 the breed effect was only significant for seasons 1 and $3\left(F_{1}=4.588\right.$; $P_{1}=0.013$ and $\mathrm{F}_{3}=4.840 ; P_{3}=0.006$ ). The results of the Bonferroni test $(90 \%)$ show that for season 1 the cholesterol content differed between breeds $\mathrm{M}, \mathrm{A} \times \mathrm{C}$ and $\mathrm{W}$; in season 3 , differences were found between breeds $\mathrm{CH}, \mathrm{A} \times \mathrm{C}$ and $\mathrm{A}$.

The authors are unaware of any other studies that compare the cholesterol content in different breeds of sheep. The results reported for other species are inconclusive. According to Homer and Virtanen [19], the inter-breed cow's milk cholesterol differences are slight or absent. Similarly, Mayer et al. [23] reported no significant effect of goat's breed (6 breeds, 15 animals each sample) for the cholesterol content in milk. However, significant breed differences in fat cholesterol contents were observed by Arora et al. [6] in 20 samples of herd goat's milk: the average values for fat percentage and total 
Table II. Correlation matrix of ovine milk cholesterol and its precursors (expressed as $\mu \mathrm{mol} \cdot \mathrm{mmol}^{-1}$ cholesterol). Effect of season ${ }^{(\mathrm{a})}$ and breed ${ }^{(\mathrm{b})}$.

\begin{tabular}{|c|c|c|c|c|}
\hline & Cholesterol & Lathosterol & Dihydrolanosterol & Lanosterol \\
\hline Squalene & $0.019^{\mathrm{a}} 0.100^{\mathrm{b}}$ & $-0.085^{\mathrm{a}}-0.033^{\mathrm{b}}$ & $0.024^{\mathrm{a}}-0.067^{\mathrm{b}}$ & $0.121^{\mathrm{a}}-0.063^{\mathrm{b}}$ \\
\hline Cholesterol & & $-0.136^{\mathrm{a}}-0.124^{\mathrm{b}}$ & $-0.169^{\mathrm{a}}-0.216^{\mathrm{b}}$ & $-0.212^{\mathrm{a}} \quad-0.309^{\mathrm{b}} * *$ \\
\hline Lathosterol & & & $0.146^{\mathrm{a}} \quad 0.294^{\mathrm{b}} * *$ & $0.318^{\mathrm{a} * *} 0.485^{\mathrm{b} * *}$ \\
\hline Dihydrolanosterol & & & & $0.412^{\mathrm{a} * *} 0.583^{\mathrm{b} * *}$ \\
\hline
\end{tabular}

$* P<0.05 ; * * P<0.01$.

cholesterol (as mg $\cdot 100 \mathrm{~g}^{-1}$ fat), respectively, were 4.1 and 387 for Alpine, 5.21 and 415 for Beetal and 5.4 and 425 for crossbred goat's milk.

Analysis of model 2 showed that the season effect was significant for breeds $\mathrm{CH}, \mathrm{M}$ and $\mathrm{W}\left(\mathrm{F}_{\mathrm{CH}}=10.56, P_{\mathrm{CH}}=0.002\right.$; $\mathrm{F}_{\mathrm{M}}=4.455, P_{\mathrm{M}}=0.015 ; \mathrm{F}_{\mathrm{W}}=5.205, P_{\mathrm{W}}=$ $0.008)$. Several pairs were found with $95 \%$ significance, largely season 1 versus others, depending on the breed. Thus, breed $\mathrm{CH}$ presented differences between seasons 1 and 2 versus 3 ; breed $M$ between season 1 versus seasons 2 and 3 ; and breed $\mathrm{W}$ presented differences between season 1 versus seasons 3 and 4 .

The cholesterol intake in the habitual diets of ruminants is very low; forages and cereals contain only trace amounts of cholesterol. Moreover, according to Homer and Virtanen [19] and Lu [22], the level of fat in food does not influence the concentrations of cholesterol in cow's and goat's milk, for which no direct relationship should be expected between the diet changes associated with the season of the year and the cholesterol content in milk. However, several authors have observed that the content of cholesterol in the milk of different species varies according to the state of lactation $[8,19,21]$ although the data analysed in these studies are expressed on total milk. In the present study, in two of the five herds births proceeded throughout the year (there was no grouping), so that the lactation period was not associated with a season. This and the fact that cholesterol is expressed in relation to fat (and not to the milk as a whole) may explain why the variations observed for the seasonal effect present no clear trend (Fig. 1).

\subsection{Correlations of ovine milk cholesterol and its precursors}

Table II shows the correlation coefficients between cholesterol and its precursors, expressed in $\mu \mathrm{mol} \cdot \mathrm{mmol}^{-1}$ cholesterol. Cholesterol precursors may be passively released into the milk proportionally to their intracellular concentrations. The concentration of squalene in milk (the first of these precursors), which is around $0.6 \%$ of the cholesterol, did not correlate with that of cholesterol (or any of the other intermediate products); however, cholesterol did correlate with lanosterol (the second precursor in its biosynthesis).

The low desmosterol content $(0.14 \%$ of cholesterol, not included in the correlation analysis), together with the correlations between lanosterol, dihydrolanosterol and lathosterol, would seem to indicate that cholesterol synthesis in the sheep mammary gland may predominantly do not follow the unsaturated-side-chain pathway. Although still preliminary, these results seem to contrast with those reported by Kalio et al. [21] for humans, in which desmosterol (which accounts for $10 \%$ of the cholesterol concentration in milk) and the cited pathway are more preponderant. 


\section{ACKNOWLEDGMENTS}

The authors are grateful to L. Barrios (Centro Técnico de Informática, CSIC) for her help with statistical analysis. This work was supported by the National Plan of Research (Project CAL01-013).

\section{REFERENCES}

[1] Addeo F., Kuzdzal-Savoie S., Chianese L., Malorni A., Sepe C., Contribution à l'étude des composés liposolubles du lait de bufflonne, Lait 61 (1981) 187-212.

[2] Al-Khalifah A., Al-Kahtani H., Composition of ghee (Samn Barri's) from cow's and sheep's milk, Food Chem. 46 (1993) $373-375$

[3] Alonso L., Fontecha J., Lozada L., Juárez M., Determination of mixtures in vegetable oils and milk fat by analysis of sterol fraction by gas chromatography, J. Amer. Oil Chem. Soc. 74 (1997) 131-135.

[4] Alonso L., Fontecha J., Lozada L., Fraga M.J., Juárez M., Fatty acid composition of caprine milk: major, branched-chain and trans fatty acids, J. Dairy Sci. 82 (1999) $878-884$

[5] Angulo A.J., Romera J.M., Ramirez M., Gil A., Determination of cholesterol oxides in dairy products. Effect of storage conditions, J. Agric. Food Chem. 45 (1997) 4318-4323.

[6] Arora K.L., Bindal M.P., Jain M.J., Variation in fat unsaponifiable matter and cholesterol contents of goat milk, Indian J. Dairy Sci. 29 (1976) 191-196.

[7] Assenat L., Le lait de brebis. Composition et propriétés, in: Luquet F.M. (Ed.), Laits et produits laitiers. Vache. Brebis. Chèvre, Technique et Documentation-Lavoisier, Paris, France, 1985, pp. 281-319.

[8] Boersna E.R., Offringa P.F., Muskiet F.A.J., Chase W.M., Vitamin E, lipid fractions and fatty acid composition of colostrum, transitional milk and mature milk: an international comparative study, Amer. J. Clin. Nutr. 53 (1991) 1197-1204.

[9] Brewington C.R., Caress E.A., Schwartz D.P., Isolation and identification of new constituents in milk fat, J. Lipid Res. 11 (1970) 355-361

[10] Chevallier F., Transferts et synthèse du cholestérol chez le rat au cours de sa croissance, Biochim. Biophys. Acta 84 (1964) 316-339.

[11] Christopherson S.W., Glass R.L., Preparation of milk fat methyl esters by alcoholysis in an essentially nonalcoholic solution, J. Dairy Sci. 52 (1969) 1289-1290.

[12] Clark R.M., Fey M.B., Jensen R.G., Hill D.W., Desmosterol in human milk, Lipids 18 (1983) 264-266.

[13] Fletouris D.J., Botsoglou N.A., Psomas I.E., Mantis A.L., Rapid determination of cholesterol in milk and milk products by direct saponification and capillary gas chromatography, J. Dairy Sci. 81 (1998) 2833-2840.

[14] Fraga M.J., Fontecha J., Lozada L., Martinez-Castro I., Juarez M., Composition of the sterol fraction of caprine milk fat by gas chromatography and mass spectrometry, J. Dairy Res. 67 (2000) 437-441.

[15] García-Olmedo R., Coll L., Estudio de la grasa de leche de ovejas españolas. Composición del insaponificable. I. Esteroles e hidrocarburos, Anal. Bromatol. 31 (1979) 38-52.

[16] García-Olmedo R., Coll L., Estudio de la grasa de leche de ovejas españolas. Composición del insaponificable. II Fracción alcohólica, Anal. Bromatol. 31 (1979) 117-126.

[17] Haddadin M.S.Y., Lubbadeh W., AlTamimi M.A., Robinson R.K., A preliminary appraisal of the effect on the cholesterol content of fresh ovine milk of supplementing the feed of Awassi ewes with Lactobacillus acidophilus, Milchwissenschaft 54 (1999) 502-505.

[18] Homberg E., Seher A., Sterol analysis for the detection of adulteration of milk fat, J. Amer. Oil Chem. Soc. 57 (1980) (2) (Abstr. 146).

[19] Homer D.R., Virtanen A.I., Cow's milk cholesterol-studies on the milk of cows on normal and protein-free feeds, Milchwissenschaft 22 (1967) 1-6.

[20] IDF. Milk fat and milk fat products. Determination of cholesterol, Standard 159. Int. Dairy Fed., Brussels, Belgium, 1992.

[21] Kallio M.J.T., Siimes M.A., Perheentupa J., Salmenperä L., Miettinen A., Cholesterol and its precursors in human milk during prolonged exclusive breast-feeding, Amer. J. Clin. Nutr. 50 (1989) 782-785.

[22] Lu C.D., Implication of feeding isoenergetic diets containing animal fat on milk composition of alpine does during early lactation, J. Dairy Sci. 76 (1993) 1137-1147. 
[23] Mayer H.K., Schober D., Ulberth F., Kneifel W., Physico-chemical characteristics of goat milk in Austria-seasonal variations and differences between breeds, in: Production and utilization of ewe and goat milk, Special Issue no. 9603. Int. Dairy Fed., Brussels, Belgium, 1996.

[24] Morice I.M., The unsaponifiable matter of butter fat, Part I. J. Chem. Soc. (1951) 1200-1203.
[25] Precht D., Cholesterol content in European bovine milk fat, Nahrung 45 (2001) 2-8.

[26] Sheppard A.J., Shen C.S.J., Rudolf T.S, Detection of vegetable oil adulteration in ice-cream, J. Dairy Sci. 68 (1985) 1103-1108.

[27] Walstra P., Jenness R., Dairy Chemistry and Physics, John Wiley \& Sons, New York, USA, 1984. 